\title{
Chrysotile Asbestos Upregulates Gene Expression and Production of $\alpha$ - Receptors for Platelet-derived Growth Factor (PDGF-AA) on Rat Lung Fibroblasts
}

James C. Bonner, Audrey L. Goodell, Patrick G. Coin, and Arnold R. Brody

Laboratory of Pulmonary Pathobiology, National Institute of Environmental Health Sciences,

Research Triangle Park, North Carolina 27709

\begin{abstract}
PDGF isoforms have been postulated to serve as mediators of fibroblast proliferation and chemotaxis during lung fibrogenesis induced by asbestos inhalation. We have studied the interaction of chrysotile asbestos fibers with rat lung fibroblasts (RLF) in vitro and the consequent changes in PDGF receptor mRNA expression, PDGF binding, and mitogenic activity of PDGF isoforms. Northern blot analysis revealed that mRNA for the PDGF-receptor $\alpha$ subtype (PDGF-R $\alpha$ ) on RLF was upregulated after a 24-h exposure to asbestos in culture (0.5$15 \mu \mathrm{g}$ fibers $\left./ \mathrm{cm}^{2}\right)$. [ $\left.{ }^{125} \mathrm{I}\right]$ PDGF-BB receptor assays showed that normal RLF possess mainly PDGF-R $\beta$ and a paucity of PDGF-R $\alpha$. In agreement with the Northern data, saturation binding of [ ${ }^{125}$ I] PDGF-BB to RLF exposed to asbestos demonstrated an $\sim 40 \%$ increase in binding sites accompanied by a twofold decrease in receptor affinity. Treating asbestos-exposed RLF with PDGF-AA, which binds only PDGF-R $\alpha$, blocked the PDGF binding sites that were upregulated by fiber exposure. PDGF-AA had increased mitogenic potency for fiber-exposed RLF, but PDGF-BB was a less potent mitogen for these RLF. Nonfibrogenic carbonyl iron spheres induced similar changes in PDGF growth responses. These data show that inorganic particulates alter the PDGF-R $\alpha$ population on RLF without significant change in PDGF-R $\beta$. ( J. Clin. Invest. 1993. 92:425-430.) Key words: platelet-derived growth factor • platelet-derived growth factor receptor • fibroblast • asbestos • fibrogenesis
\end{abstract}

\section{Introduction}

PDGF is a disulfide-linked polypeptide comprised of two chains ( $A$ and $B$ ) that give rise to three dimeric isoforms termed PDGF-AA, PDGF-AB, and PDGF-BB (1). Two PDGF receptor subtypes have been identified. The $\alpha$ receptor subtype (PDGF-R $\alpha)^{1}$ binds either the A or B chain of PDGF, while the $\beta$ receptor subtype (PDGF-R $\beta$ ) binds only the $B$ chain $(2,3)$. PDGF isoforms binding to either PDGF-R $\alpha$ or PDGF-R $\beta$ cause dimerization of receptor molecules $(\alpha \alpha, \alpha \beta$, $\beta \beta$ ) closely associated with receptor kinase activation (4).

Address correspondence to James C. Bonner, Maildrop D2-02, National Institute of Environmental Health Sciences, Research Triangle Park, NC 27709.

Received for publication 30 July 1992 and in revised form 19 January 1993.

1. Abbreviations used in this paper: PDGF-R $\alpha$, PDGF-receptor $\alpha$ subtype; PDGF-R $\beta$, PDGF-receptor $\beta$ subtype; PPP, platelet-poor plasma; $R L F$, rat lung fibroblasts.

The Journal of Clinical Investigation, Inc.

Volume 92, July 1993, 425-430
Some cell types such as human skin fibroblasts (5) and vascular smooth muscle cells (6) possess mainly PDGF-R $\beta$ with a relatively low number of PDGF-R $\alpha$, while other cells types such as Swiss mouse 3T3 cells possess approximately equal numbers of both receptor subtypes (5).

PDGF-like molecules secreted by smooth muscle cells (7), endothelial cells ( 8 ), and macrophages (9) have been proposed as mediators in the progression of several fibrotic disorders, including atherosclerosis $(10,11)$ and pulmonary interstitial fibrosis $(12,13)$. Both of these diseases are characterized by an increase in mesenchymal cell migration and proliferation, as well as by increases in extracellular matrix deposition. PDGF could be important both in directing the migration of fibroblasts (14) and smooth muscle cells (15) and in stimulating the fibroproliferative response of these cells.

Alveolar macrophages have been implicated as an important source of PDGF in the lung. Macrophages produce at least two molecular weight forms of PDGF $(9,16)$ and these predominantly B-chain molecules are potent mitogens and chemoattractants $(9,17)$ for mesenchymal cells. Furthermore, activation of alveolar macrophages by exposure to asbestos fibers increases secretion of PDGF-like factors severalfold and we have previously described paracrine signaling between these activated macrophages and normal rat lung fibroblasts (RLF) via PDGF (16). These normal RLF possess predominantly PDGF-R $\beta$ with a relatively low number of PDGF-R $\alpha$. Accordingly, they have a strong mitogenic response to PDGF-BB, but not to PDGF-AA.

The effect of asbestos on the expression of PDGF receptors by RLF has not been addressed. We have shown in an animal model that inhaled asbestos fibers reach the lung interstitium by translocation through the alveolar epithelium (18). These fibers interact with macrophages and mesenchymal cells (19), inducing a fibroproliferative process which clearly mimics components of several human diseases including asbestosis (20) and idiopathic pulmonary fibrosis (21). Herein, we report that an in vitro exposure of RLF to chrysotile asbestos upregulates the gene expression and production of cell-surface PDGF-R $\alpha$. This increase in the PDGF-R $\alpha$ makes these cells more responsive to PDGF-AA, but less responsive to PDGF-BB. Establishing the mechanism(s) by which this receptor population is changed could be important to our understanding of fibroproliferative lung disease and the progression of interstitial pulmonary fibrosis.

\section{Methods}

Fibroblasts. Swiss 3T3 cells were purchased from American Type Culture Collection (Rockville, MD) and were maintained in 10\% FBS/ RPMI. Early passage RLF were isolated and characterized as described elsewhere (13). For the cell proliferation and receptor assays described below, rat lung fibroblasts and Swiss 3T3 cells were taken out of cryopreservation and grown to near confluence for 3-4 d, then trypsinized 
and seeded at an appropriate density. These RLF were designated as passage 3 .

Northern analysis for PDGF $\alpha$-receptor $m R N A$. RLFs were grown to confluence in $150 \mathrm{~cm}^{2}$ flasks in $10 \%$ FBS-DMEM and then rendered quiescent for $24 \mathrm{~h}$ in serum-free defined medium (Ham's F-12 with Hepes, $\mathrm{CaCl}_{2}$, and $0.25 \% \mathrm{BSA}$ supplemented with an insulin/transferrin/selenium mixture purchased from Boehringer Mannheim Biochemicals, Indianapolis, IN) before treating with fresh serum-free defined medium alone or supplemented with chrysotile asbestos (0.5-15 $\left.\mu \mathrm{g} / \mathrm{cm}^{2}\right)$. This concentration range of asbestos caused no significant decrease in cell viability over a 24-h period as determined by trypan blue exclusion. However, asbestos concentrations between 5 and 15 $\mu \mathrm{g} / \mathrm{cm}^{2}$ caused some cell mortality in a 3-d growth assay (see below). After a 24-h exposure of the RLF to asbestos, the cells were trypsinized and pelleted by centrifugation. Cells were lysed in guanidinium thiocyanate containing 2-mercaptoethanol to liberate total RNA as described previously (22). 20- $\mu \mathrm{g}$ aliquots of total RNA were subjected to electrophoresis on $1.2 \%$ agarose $/ 2 \mathrm{M}$ formaldehyde gels and vacuum transferred onto Immobilon N membrane (Millipore Corp., Bedford, MA). The membranes were baked at $80^{\circ} \mathrm{C}$ for $1 \mathrm{~h}$ before an overnight prehybridization at $63^{\circ} \mathrm{C}$ in $50 \mathrm{mM}$ potassium phosphate buffer containing $6 \times$ SSC, $5 \times$ Denhardt's, $2 \%$ SDS, and $10 \mu \mathrm{g} / \mathrm{ml}$ herring sperm DNA. Membranes were then hybridized overnight with $5 \times 10^{6} \mathrm{cpm} / \mathrm{ml}$ of labeled cDNA probe at $63^{\circ} \mathrm{C}$ in the same buffer, followed by washing at $63^{\circ} \mathrm{C}$ to a final stringency of $0.2 \times$ SSC with $0.5 \%$ SDS. The autoradiographic signal of the cDNA hybridizing mRNA was visualized by exposing the membrane to Kodak XAR-5 film for 3-5 d. We used the A549 (American Type Culture Collection ) epithelial cell line as a negative control for PDGF-R $\alpha$ expression and human lung fibroblasts kindly provided by Dr. Anton Jetten (National Institute of Environmental Health Sciences, Research Triangle Park, NC) as a positive control for PDGF-R $\alpha$ expression. The human cDNA probe for the PDGF-R $\alpha$ subunit, kindly provided by Dr. Carl Henrik-Heldin (Ludwig Institute for Cancer Research, Uppsala, Sweden), was labeled with a random primed DNA labeling kit (Boehringer Mannheim Biochemicals). The PDGF-R $\alpha$ cDNA covers the tyrosine kinase area in the receptor and hybridizes with a $6.5-\mathrm{kb}$ transcript $(23)$.

$\left[{ }^{125}\right.$ I]PDGF-BB receptor assay. Rat lung fibroblasts were seeded 1 $\times 10^{6} / 150 \mathrm{~cm}^{2}$ flask in $10 \%$ FBS-DMEM and grown to near confluence $(5-7 \mathrm{~d})$. These cells were trypsinized, plated $5 \times 10^{4}$ cells $/$ well in 24-well $\left(2-\mathrm{cm}^{2}\right)$ dishes, and grown for $2-3 \mathrm{~d}$ until $\sim 70 \%$ confluent. At this time the $10 \%$ FBS was aspirated and replaced with $1 \%$ FBS for $24 \mathrm{~h}$ to render the cells quiescent. Plates of cells were either exposed to asbestos $\left(5 \mu \mathrm{g} / \mathrm{cm}^{2}\right)$ in $1 \%$ FBS-DMEM for an additional $24 \mathrm{~h}$ before assay or incubated with medium alone. The plates were then cooled to 0-4 $4^{\circ} \mathrm{C}$ for $15-30 \mathrm{~min}$, the $1 \%$ FBS aspirated, and the cells washed twice with ice-cold binding buffer (Ham's F-12 buffered at pH 7.4 with 25 $\mathrm{mM}$ Hepes, $\mathrm{CaCl}_{2}$, and $0.25 \% \mathrm{BSA}$ ). [ ${ }^{125} \mathrm{I}$ ] PDGF-BB (NEN-DuPont, Wilmington, DE) possessing a sp act of $29-53 \mu \mathrm{Ci} / \mu \mathrm{g}$ was diluted to $200 \mathrm{ng} / \mathrm{ml}$ in binding buffer. Saturation binding assays were performed by adding increasing amounts $(0.5-20 \mathrm{ng} / \mathrm{ml})$ of [ $\left.{ }^{125} \mathrm{I}\right]$ PDGFBB to cells in duplicate wells in a final vol of $0.2 \mathrm{ml} /$ well. After incubating on an oscillating platform at $0-4^{\circ} \mathrm{C}$ for $3 \mathrm{~h}$, the cells were washed three times with ice-cold binding buffer, the cell-bound radioactivity solubilized with $1 \%$ Triton $\mathrm{X}$ containing $0.1 \% \mathrm{BSA}$, and the radioactivity measured on a gamma counter. Cells incubated with [ $\left.{ }^{125} \mathrm{I}\right]$ PDGF$B B$ alone were used to measure total binding. Nonspecific binding was determined in the presence of $500 \mathrm{ng} / \mathrm{ml}$ nonradioactive PDGF-BB and was less than $\sim 10 \%$ of the total binding. Specific binding was defined as the difference between total and nonspecific at each concentration of radioligand. To inhibit [ $\left.{ }^{125} \mathrm{I}\right]$ PDGF-BB binding to PDGF$\mathrm{R} \alpha$, parallel cultures were preincubated with $50 \mathrm{ng} / \mathrm{ml}$ nonradioactive PDGF-AA for $1 \mathrm{~h}$ at $37^{\circ} \mathrm{C}$ before performing the binding assay according to the method described by Seifert et al. (5). This allowed a quantitation of the numbers of $\alpha$ and $\beta$ receptor subunits per cell following Scatchard analysis of the saturation binding data (24).

Cell proliferation assay. RLF suspended in 10\% FBS-DMEM were seeded $2 \mathrm{ml} /$ well in 12-well tissue culture plates at 20,000/well and allowed to proliferate for $24 \mathrm{~h}$ in $5 \% \mathrm{CO}_{2}$ humidified air at $37^{\circ} \mathrm{C}$. The cells were washed $2 \times$ after $24 \mathrm{~h}$ with serum-free DMEM and then received 5\% rabbit platelet-poor plasma (PPP), prepared as described previously (13), that contained increasing concentrations of human recombinant PDGF-AA or PDGF-BB homodimers (Upstate Biotechnology Inc., Lake Placid, NY). Parallel incubations were coincubated with $5 \mu \mathrm{g} / \mathrm{cm}^{2}$ chrysotile asbestos or carbonyl iron. After $3 \mathrm{~d}$ of incubation, the growth medium was aspirated and the cells harvested by trypsinization and enumerated using a Coulter Counter (Coulter Electronics, Hialeah, FL). In another experiment, RLF maintained for $24 \mathrm{~h}$ in $10 \%$ FBS-DMEM were rendered quiescent for $3 \mathrm{~d}$ in $1 \%$ FBS-DMEM and then treated with PDGF-AA or PDGF-BB alone or with asbestos for an additional $3 \mathrm{~d}$. Thus, we studied the effect of asbestos on RLF proliferation when the cells were either quiescent or in log phase growth.

\section{Results}

Asbestos increases PDGF-R $\alpha$ mRA expression. We observed that PDGF-R $\alpha$ receptor gene expression was increased after a 24-h exposure to asbestos (Fig. $1 A$ ). The PDGF-R $\alpha$ cDNA probe hybridized with transcripts at $\sim 6.5 \mathrm{~kb}$. Barely detectable levels of receptor message were observed in unexposed RLF. The expression of PDGF-R $\alpha$ was increased maximally by asbestos in the concentration range $0.5-5 \mu \mathrm{g} / \mathrm{cm}^{2}$ of culture surface. For this reason, we used $5 \mu \mathrm{g} / \mathrm{cm}^{2}$ asbestos for the experiments on receptor binding and growth assays described below. The A549 cell line expressed no detectable level of PDGF-R $\alpha$ mRNA, while the human lung fibroblasts expressed a strong signal for this receptor. Ethidium bromide staining of the $18 \mathrm{~S}$ and $28 \mathrm{~S}$ mRNA was performed to compare total ribo-

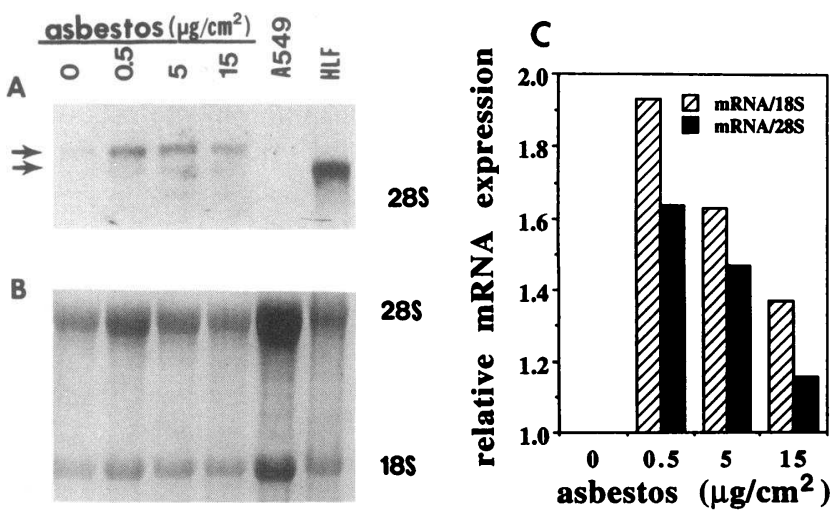

Figure 1. Upregulation of PDGF-R $\alpha$ mRNA by Northern blot analysis. RLF were allowed to grow to confluence in $150-\mathrm{cm}^{2}$ flasks in $10 \%$ FBS-DMEM and then rendered quiescent in serum-free defined medium for $24 \mathrm{~h}$ before adding suspensions of chrysotile asbestos for an additional $24 \mathrm{~h}$. The cells were then trypsinized, resuspended in DMEM supplemented with soybean trypsin inhibitor, and centrifuged to pellet the cells. After washing the pellet in PBS and pelleting once more, the mRNA was isolated and Northern analysis performed as described in Methods. $(A)$ Autoradiograph showing the expression of PDGF-R $\alpha$ mRNA in unexposed and asbestos-exposed RLF. Negative and positive controls for PDGF-R $\alpha$ expression were A549 cells and human lung fibroblasts, respectively. $(B)$ Ethidium bromide staining of $18 \mathrm{~S}$ and $28 \mathrm{~S} \mathrm{mRNA}$ from the same experiment shown in $A$. (C) Scanning densitometric analysis of the data shown in $A$ and $B$ demonstrating a nearly twofold increase in PDGF-R $\alpha$ mRNA expression relative to either $18 \mathrm{~S}$ or $28 \mathrm{~S}$ RNA following asbestos exposure. The results shown are typical of three separate experiments. 
somal RNA from RLF preparations (Fig. $1 B$ ). Scanning densitometry was performed on both the PDGF-R $\alpha$ mRNA and total RNA ethidium bromide negatives. Using the ratio of PDGF-R $\alpha$ mRNA/total RNA for either $18 \mathrm{~S}$ or $28 \mathrm{~S}$, we observed a nearly twofold increase PDGF-R $\alpha$ mRNA after asbestos exposure (Fig. 1C).

Asbestos exposure increases the number of $\left[{ }^{125} \Pi\right] P D G F-B B$ binding sites. Specific [ ${ }^{125}$ I] PDGF-BB binding to RLF saturated at $\sim 10 \mathrm{ng} / \mathrm{ml}$ of radioligand (Fig. $2 A$ ). Scatchard analysis of the these saturation data demonstrated RLF possessed a maximal number of [ $\left.{ }^{125} \mathrm{I}\right]$ PDGF-BB binding sites (maximal binding capacity) of $60-70 \mathrm{fmol} / 10^{6}$ cells with a $K_{\mathrm{d}}$ of $0.12 \mathrm{nM}$ (Fig. $2 B$ ). Treatment with $5 \mu \mathrm{g} / \mathrm{cm}^{2}$ of chrysotile asbestos for $24 \mathrm{~h}$ increased the saturation binding plateau (Fig. $2 \mathrm{C}$ ), and Scatchard analysis of these data indicated a significant increase in the number of binding sites (maximal binding capacity $=120 \mathrm{fmol} / 10^{6}$ cells). However, asbestos exposure decreased twofold the relative affinity that [ ${ }^{125}$ I] PDGF-BB possessed for its receptors $\left(K_{\mathrm{d}}=0.25 \mathrm{nM}\right)$ relative to untreated cells (Fig. 2 $D)$. Although asbestos treatment caused some increase in the amount of nonspecific binding in the receptor assay, this could not be attributed to the alterations observed in high-affinity specific binding.

Pretreatment of fibroblasts with PDGF-AA blocks $\left[{ }^{125} \Pi\right]-$ $P D G F-B B$ binding sites that are upregulated by asbestos. Since the PDGF-BB isoform binds to all three receptor dimers, it was necessary to determine which receptor subunit was increased after asbestos exposure. We incubated RLF with asbestos or serum-free defined medium alone for $24 \mathrm{~h}$ and then incubated the cells with $50 \mathrm{ng} / \mathrm{ml}$ nonradioactive PDGF-AA to occupy only the PDGF-R $\alpha$ subunits. Using this technique, our studies with unexposed RLF and Swiss 3T3 cells demonstrated that PDGF-AA preincubation reduced [ ${ }^{125}$ I] PDGF-BB binding to RLF by $<5 \%$, while [ ${ }^{125}$ I] PDGF-BB binding to Swiss 3 T 3 cells was reduced $\sim 50 \%$ (Fig. $3 A$ ). We further observed that the increase in [ $\left.{ }^{125} \mathrm{I}\right]$ PDGF-BB binding sites after asbestos exposure (increase in the $x$ intercept of the Scatchard plot) could be blocked by preincubation with PDGF-AA (Fig. $3 C$ ). This PDGF-AA preincubation also returned the relative affinity constant $\left(K_{\mathrm{d}}=0.13-0.14 \mathrm{nM}\right)$ for [ $\left.{ }^{125} \mathrm{I}\right]$ PDGF-BB to that observed for control RLFs.
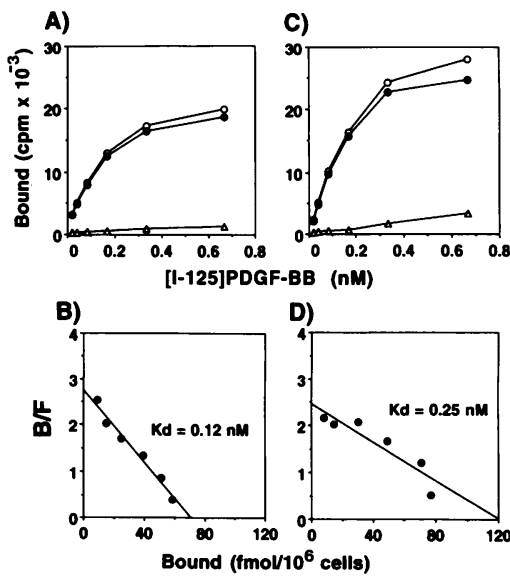

Figure 2. ( $A$ ) Saturation binding of [ ${ }^{125}$ I] PDGF. BB to RLF. (B) Scatchard analysis of the saturation binding data for control RLF. $(C)$ Saturation binding of [ ${ }^{125}$ I] PDGF-BB to RLFs exposed for $24 \mathrm{~h}$ to $5 \mu \mathrm{g} / \mathrm{cm}^{2}$ chrysotile asbestos fibers. $(D)$ Scatchard analysis of the saturation binding data for asbestos-treated RLF. [ ${ }^{125}$ I] PDGF-BB binding assays were performed as described in Methods. Asbestos

caused a twofold decrease in PDGF-BB receptor affinity accompanied by a $40 \%$ increase in PDGF-BB binding sites. The results are typical of four separate experiments.
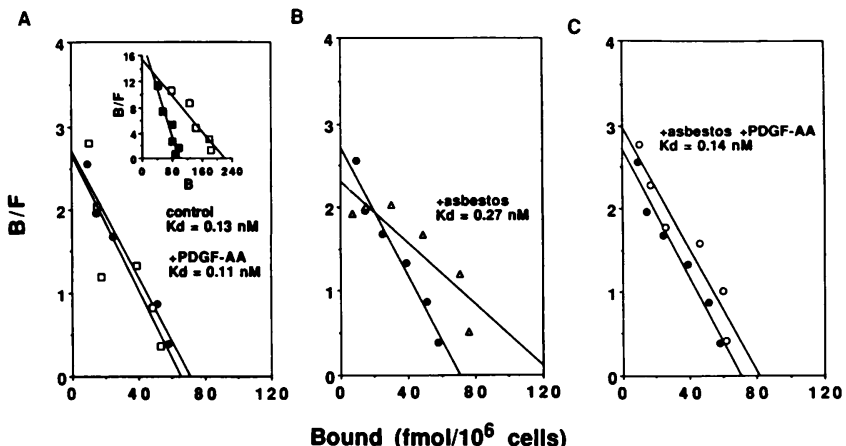

Figure 3. The effect of a 1-h pretreatment with $50 \mathrm{ng} / \mathrm{ml}$ PDGF-AA on the Scatchard plots for RLF $(A)$ and Swiss 3T3 cells (inset). Closed circles represent control RLF plots and open squares designate the effect of PDGF-AA treatment on these control fibroblasts. The control plot for Swiss 3T3 cells is symbolized by open squares and closed squares designate the effect of PDGF-AA treatment. Measurement of the increased number of [ ${ }^{125}$ I]PDGF-BB binding sites on RLFs exposed to asbestos for $24 \mathrm{~h}$ at $37^{\circ} \mathrm{C}$ designated by open triangles $(B)$ is blocked by incubating the asbestos-exposed cells for $1 \mathrm{~h}$ at $37^{\circ} \mathrm{C}$ with $50 \mathrm{ng} / \mathrm{ml}$ PDGF-AA as symbolized by open circles $(C)$. The results are typical of four separate experiments.

Upregulation of cell-surface PDGF-BB binding sites is due to a selective increase in the $\alpha$-receptor subunit. Using the method described by Seifert and colleagues (5), we calculated the numbers of $\alpha$ and $\beta$ receptor subunits per million cells (Fig. 4). This can be accomplished based on the model that assumes [ ${ }^{125}$ I] PDGF-BB binds and dimerizes PDGF-R $\alpha$ and PDGF$\mathrm{R} \beta$ subunits (5), whereas cells preincubated with PDGF-AA possess only PDGF-R $\beta$ subunits to bind [ ${ }^{125}$ I] PDGF-BB, and the difference between these two measurements yields the number of PDGF-R $\alpha$ subunits. For cells not exposed to asbestos, we found that RLF possessed mainly PDGF-R $\beta(\sim 20,000$ bind-

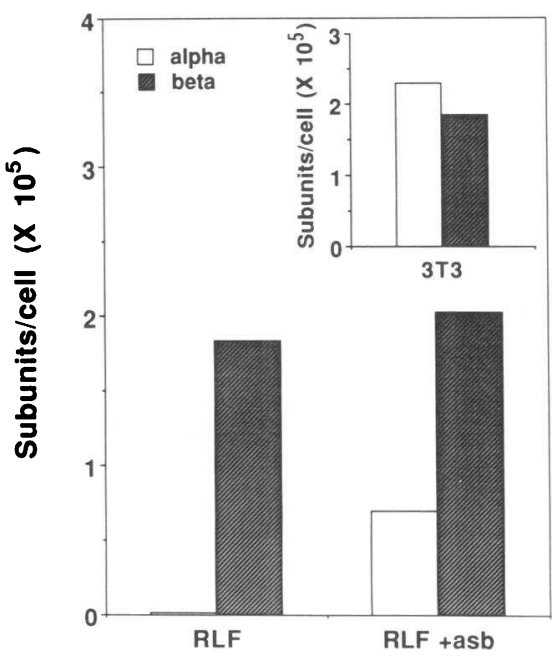

Figure 4. Numbers of PDGF-R $\alpha$ and PDGF-R $\beta$ receptor subunits calculated from the saturation binding shown in Fig. 3. Normal RLF possess barely detectable levels of PDGF-R $\alpha$ (open bar), and have an abundance of PDGF-R $\beta$ ( hatched bar). Asbestos treatment upregulates the PDGF-R $\alpha$ (open bar), but has no appreciable effect on numbers of PDGF-R $\beta$ ( hatched bar). Swiss 3T3 cells, used as a control, possess approximately equal numbers of PDGF-R $\alpha$ and PDGF$\mathrm{R} \beta$ receptor subunits (inset). 
ing sites per cell), while Swiss 3T3 had approximately equal numbers of $\alpha$ and $\beta$ receptors.

Asbestos-exposed fibroblasts are more responsive to PDGF$A A$, but less responsive to $P D G F-B B$. As we previously reported (16), RLF incubated with PDGF-AA in the concentration range $0.5-20 \mathrm{ng} / \mathrm{ml}$ proliferated minimally or not at all to PDGF-AA (Fig. $5 \mathrm{~A}$ ). However, asbestos-exposed RLF grown in the presence of PDGF-AA showed a significant concentration-dependent increase in cell proliferation after $3 \mathrm{~d}$ (Fig. 5 $A$ ). Thus, asbestos exposure altered RLF responsiveness to PDGF-AA. We also reported that PDGF-BB was a potent mitogen for RLF (16). Here we show that asbestos exposure made these cells less responsive to PDGF-BB in the concentration range $0.5-20 \mathrm{ng} / \mathrm{ml}$ (Fig. $5 \mathrm{~B}$ ). Exposure of RLF to carbonyl iron spheres $\left(5 \mu \mathrm{g} / \mathrm{cm}^{2}\right)$ elicited a similar pattern of growth responsiveness to PDGF-AA and PDGF-BB as compared to asbestos (Fig. 5, $C$ and $D$ ).

Asbestos exposure positively or negatively influences fibroblast growth, depending on the growth state. Asbestos exposure either enhanced or inhibited RLF proliferation, depending on whether the cells were quiescent or in log phase growth, respectively (Fig. 6). An 25\% mortality of RLF was observed after $3 \mathrm{~d}$ when the cells were treated with $5 \mu \mathrm{g} / \mathrm{cm}^{2}$ asbestos immediately after a 24-h growth period in 10\% FBS-DMEM (i.e., the cells were in log phase growth). However, when the RLF were maintained in low serum medium ( $1 \%$ FBS-DMEM) for $3 \mathrm{~d}$ after the removal of the 10\% FBS-DMEM to render the cells quiescent and then exposed to asbestos, an $\sim 40 \%$ increase in cell number was observed (Fig. 6). Importantly, the same pattern of growth responsiveness of asbestos-exposed cells (i.e., increased proliferation to PDGF-AA and decreased response to -BB as shown in Fig. 5) was observed with RLF treated either in log phase (Fig. 5) or in a quiescent growth state (data not shown).
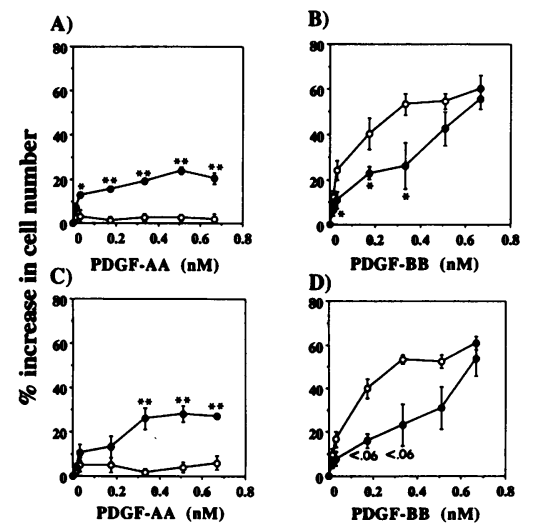

Figure 5. Alteration in the RLF mitogenic response to PDGF-AA and -BB by asbestos and carbonyl iron. Fibroblasts were plated in $10 \%$ FBS-DMEM and incubated for $24 \mathrm{~h}$ as described in Methods before adding 5\% PPP supplemented with PDGF isoforms in the absence or presence of particulates. Cells were enumerated after $3 \mathbf{d}$ in culture. Open circles represent control cells and closed circles represent particulate-treated cells. $(A)$ RLF responded to PDGF-AA after asbestos treatment ( 5 $\mu \mathrm{g} / \mathrm{cm}^{2}$ ), whereas unexposed cells showed a minimal mitogenic response. ( $B$ ) PDGF-BB was a potent mitogen for unexposed RLF, but the response of RLF to this isoform is lessened when exposed to asbestos fibers. $(C)$ RLF response to PDGF-AA after iron treatment ( 5 $\mu \mathrm{g} / \mathrm{cm}^{2}$ ) as compared to unexposed cells. (D) PDGF-BB stimulated growth of control and iron-exposed RLF. The results are expressed as the mean \pm SEM of four separate experiments each performed in triplicate. Significant differences in mitogenic response between asbestosexposed and unexposed cells at a given concentration of PDGF were determined by paired $t$ test $\left({ }^{* *} P<0.01,{ }^{*} P<0.05, P<0.06\right)$.

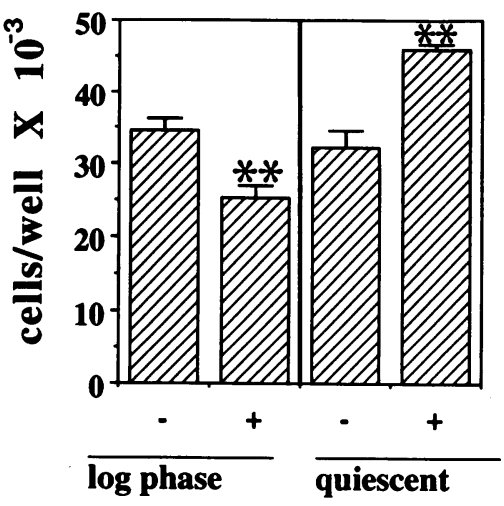

Figure 6. The effect of asbestos on RLF proliferation in the absence of exogenous PDGF. Fibroblasts were seeded 20,000 cells/well in 12 well culture dishes for $24 \mathrm{~h}$ in $10 \%$ FBSDMEM. At this time the cells were in log phase growth. The medium was aspirated and replaced with 5\% PPP alone $(-)$ or supplemented with $5 \mu \mathrm{g} / \mathrm{cm}^{2}$ asbestos $(+)$. After $3 \mathrm{~d}$ in culture, asbestos caused a significant decrease in cell number as determined by paired $t$ test $\left({ }^{* *} P<0.01\right)$. In parallel dishes, RLF were plated in 10\% FBS-DMEM for $24 \mathrm{~h}$ as described above, but the medium was replaced with $1 \%$ FBS-DMEM to render cells quiescent for $3 \mathrm{~d}$ before adding 5\% PPP containing asbestos. Under these circumstances, asbestos exposure induced an significant increase in cell number. The results are expressed as the mean \pm SEM of four separate experiments each assayed in triplicate.

\section{Discussion}

We have described an increased expression of PDGF-R $\alpha$ mRNA and a consequent alteration in the binding of PDGF$B B$ to early passage RLF after an in vitro exposure to chrysotile asbestos fibers. Both asbestos fibers (a fibrogenic agent) and carbonyl iron spheres (a nonfibrogenic particulate) caused RLF to increase their mitogenic response to PDGF-AA, whereas normally these cells proliferate minimally or not at all to this isoform because of the very low number of PDGF-R $\alpha$ present at the cell surface. In experiments with asbestos, the increased response to PDGF-AA correlated with both an increase in PDGF-R $\alpha$ gene expression and in the production of cell surface PDGF-R $\alpha$.

The proliferative response of RLF to PDGF-BB also was altered. While the increased mitogenic response to PDGF-AA is caused by a selective upregulation of PDGF-R $\alpha$, the reason for the decrease in PDGF-BB induced mitogenesis after asbestos exposure is unknown. We hypothesize that this decrease is due to a lower affinity of PDGF-BB for PDGF-R $\alpha$ as compared to PDGF-R $\beta$ and our data support this postulate. PDGF-R $\alpha$, which binds both PDGF-A and -B chains $(2,3)$, was increased, while PDGF-R $\beta$, which binds only the B chain of PDGF, apparently was unchanged (Fig. 4). Thus, the reduced mitogenic effect of relatively low concentrations of PDGF-BB on asbestos-exposed cells (Fig. 5) could be related to a lower binding affinity of PDGF-BB for PDGF receptors on these exposed fibroblasts (Fig. 2). In support of this hypothesis, we observed that [ ${ }^{125}$ I] PDGF-BB had an approximately fourfold higher affinity for PDGF-R on Swiss 3T3 cells that were pretreated with excess PDGF-AA as compared to untreated cells (Fig. 3). Because PDGF-AA blocked PDGF-R $\alpha$ only, we were able to measure the dissociation constant for PDGF-R $\beta$ alone $\left(K_{\mathrm{d}}\right.$ $=0.07 \mathrm{nM}$ ) as well as the constant for an approximately equal mixture of PDGF-R $\alpha$ and PDGF-R $\beta\left(K_{\mathrm{d}}=0.27 \mathrm{nM}\right)$.

The mechanism(s) by which inorganic particulates upregulate PDGF-R $\alpha$ production is not known. Asbestos could directly activate second messenger pathways that stimulate the transcription of PDGF-R $\alpha$ mRNA. Other workers have shown that asbestos activates second messengers such as protein ki- 
nase $\mathrm{C}$ and inositol phospholipids in tracheal epithelial cells $(25,26)$. On the other hand, inorganic particulates could stimulate the production of cytokines that are known to selectively increase PDGF-R $\alpha$. IL- $1 \beta$ has been reported to upregulate PDGF-R $\alpha$ production by an osteoblast-like cell line (27) and basic fibroblast growth factor increases PDGF-R $\alpha$ expression by vascular smooth muscle cells (28). TGF- $\beta$ has been reported to inhibit PDGF-R $\alpha$ production by smooth muscle cells (29) and Swiss 3T3 cells (30), or enhance PDGF-R $\alpha$ expression by scleroderma fibroblasts ( 31 ). Thus, cytokines could act both as positive and negative regulators of PDGF-R $\alpha$ expression.

Both asbestos fibers and carbonyl iron spheres increased the growth response to PDGF-AA. Therefore both fibrogenic and nonfibrogenic particulates upregulate PDGF-R $\alpha$ in vitro. The fates of the two particulates in vivo, however, are quite different. Inhaled carbonyl iron spheres are cleared from the lung largely by alveolar macrophages which transport them to the mucociliary escalator and the particles are not translocated to the interstitium $(32,33)$. In contrast, deposited chrysotile asbestos fibers are not cleared efficiently and are translocated to the pulmonary interstitium where they can interact with fibroblasts (18-20). Therefore, our observations are consistent with a role for PDGF-R $\alpha$ alteration in our model of asbestos-induced interstitial fibrosis.

We have pursued the hypothesis that alveolar macrophages are effectors of lung fibroblast proliferation and chemotaxis during asbestos-induced fibrogenesis. This reasoning is due in part to the observation that rat alveolar macrophages accumulate at sites of asbestos deposition and a variety of cell types (epithelial, mesenchymal, endothelial) in close proximity to the alveolar duct bifurcations undergo DNA synthesis (33, 34). We have reported that asbestos-activated macrophages secrete mainly PDGF-BB and normal RLF possess a predominance of PDGF-R $\beta(16)$. However, an upregulation of PDGF$\mathrm{R} \alpha$ could implicate the RLF as an autocrine effector of its own growth, inasmuch as fibroblasts and smooth muscle cells secrete mostly PDGF-AA (35).

PDGF-AA and PDGF-BB are potent mitogens and chemoattractants when the responding cells possess both PDGF$\mathrm{R} \alpha$ and PDGF-R $\beta$ (36). On the other hand, a number of cell types including smooth muscle cells (6), dermal fibroblasts (37), and RLF possess mainly PDGF-R $\beta$. In light of our current findings, we postulate that increased PDGF-R $\alpha$ expression induced by asbestos fibers is the mechanism through which RLF are rendered more responsive to PDGF-AA in both autocrine and paracrine pathways. Exposing RLF to asbestos in a quiescent growth state without adding any exogenous growth factors resulted in a $40 \%$ increase in RLF number after $3 \mathrm{~d}$ (Fig. 6). Thus, asbestos fibers apparently stimulate these fibroblasts to produce growth factor(s) (38), and preliminary data using antibodies to PDGF suggest that this is the primary factor involved (unpublished observation, Dr. J. A. Lasky, National Institute of Environmental Health Sciences). We also speculate that PDGF-BB released by activated macrophages $(16,39)$ is a likely mediator of the chemotactic migration of RLF to developing fibrotic lesions and of further RLF proliferation at this site. Elucidating the relative contribution of macrophage and fibroblast-derived growth factors in the progression of the fibroproliferative lesions induced by asbestos could be paramount to developing a therapeutic regimen for the treatment of interstitial fibrosis in general.
In summary, we have shown that chrysotile asbestos fibers increase the numbers of PDGF-BB binding sites on rat lung fibroblasts and that this increase is due to an upregulation of PDGF-R $\alpha$ mRNA. The increase in PDGF-BB binding sites is accompanied by an approximately twofold decrease in receptor affinity. The increase in PDGF-R $\alpha$ allows these fibroblasts to be more responsive to the mitogenic activity of PDGF-AA, but less responsive to PDGF-BB. The results presented in this paper suggest that alteration of the PDGF-R $\alpha$ population on lung fibroblasts after asbestos exposure could be a mechanism involved in pulmonary fibrogenesis.

\section{References}

1. Ross, R., E. W. Raines, and D. F. Bowen-Pope. 1986. The biology of platelet-derived growth factor. Cell. 46:155-169.

2. Hart, C. E., J. W. Forstrom, J. D. Kelly, R. A. Seifert, R. A. Smith, R. Ross, M. J. Murray, and D. F. Bowen-Pope. 1988. Two classes of PDGF receptor recognize different isoforms of PDGF. Science (Wash. DC). 240:1529-1531.

3. Heldin, C.-H., G. Backstrom, A. Ostman, A. Hammacher, L. Ronnstrand, K. Rubin, M. Nister, and B. Westermark. 1988. Binding of different dimeric forms of PDGF to human fibroblasts: evidence for two separate receptors. $E M B O$ (Eur. Mol. Biol. Organ.) J. 7:1387-1393.

4. Heldin, C.-H., A. Ernslund, C. Rorsman, and L. Ronnstrand. 1989. Dimerization of B-type platelet-derived growth factor receptors occurs after ligand binding and is closely associated with receptor kinase activation. J. Biol. Chem. 264:8905-8912.

5. Seifert, R. A., C. E. Hart, P. E. Phillips, J. W. Forstrom, R. Ross, M. J. Murray, and D. F. Bowen-Pope. 1989. Two different subunits associate to create isoform-specific platelet-derived growth factor receptors. J. Biol. Chem. 264:8771-8778.

6. Sachinidis, A., R. Locher, W. Vetter, D. Tatje, and J. Hoppe. 1990. Different effects of platelet-derived growth factor isoforms on rat vascular smooth muscle cells. J. Biol. Chem. 265:10238-10243.

7. Sjolund, M., U. Hedin, T. Sejersen, C. Heldin, and J. Thyberg. 1988. Arterial smooth muscles cells express platelet-derived growth factor (PDGF) A chain mRNA, secrete a PDGF-like mitogen, and bind exogenous PDGF in a phenotype- and growth state-dependent manner. J. Cell Biol. 106:403-413.

8. DiCorleto, P. E., and D. F. Bowen-Pope. 1983. Cultured endothelial cells produce a platelet-derived growth factor-like protein. Proc. Natl. Acad. Sci. USA. 80:1919-1923.

9. Shimokado, K., E. W. Raines, D. K. Madtes, T. B. Barrett, E. P. Benditt, and R. Ross. 1985. A significant part of macrophage-derived growth factor consists of at least two forms of PDGF. Cell. 43:277-286.

10. Barrett, T. B., and E. P. Benditt. 1988. Platelet-derived growth factor gene expression in human atherosclerotic plaques and normal artery wall. Proc. Natl. Acad. Sci. USA. 85:2810-2814.

11. Ross, R. 1986. The pathogenesis of atherosclerosis: an update. N. Engl. J. Med. 314:488-500.

12. Martinet, Y., W. N. Rom, G. R. Grotendorst, G. R. Martin, and R. G. Crystal. 1987. Exaggerated spontaneous release of platelet-derived growth factor by alveolar macrophages from patients with idiopathic pulmonary fibrosis. $N$. Engl. J. Med. 317:202-209.

13. Kumar, R. K., R. A. Bennett, and A. R. Brody. 1988. A homologue of platelet-derived growth factor produced by rat alveolar macrophages. FASEB (Fed. Am. Soc. Exp. Biol.) J. 2:2272-2277.

14. Seppa, H., G. Grotendorst, S. Seppa, E. Schiffman, and G. R. Martin 1982. Platelet-derived growth factor is chemotactic for fibroblasts. J. Cell Biol. 92:584-588.

15. Grotendorst, G. R., T. Chang, H. E. J. Seppa, K. H. Kleinman, and G. R. Martin. 1982. Platelet-derived growth factor is a chemoattractant for vascular smooth muscle cells. J. Cell. Physiol. 113:261-266.

16. Bonner, J. C., A. R. Osornio-Vargas, A. Badgett, and A. R. Brody. 1991. Differential proliferation of rat lung fibroblasts induced by the platelet-derived growth factor ( PDGF)-AA, -AB, and - BB isoforms secreted by rat alveolar macrophages. Am. J. Respir. Cell Mol. Biol. 5:539-547.

17. Osomio-Vargas, A. R., J. C. Bonner, A. Badgett, and A. R. Brody. 1990. Rat alveolar macrophage-derived PDGF is chemotactic for rat lung fibroblasts. Am. J. Respir. Cell Mol. Biol. 3:595-602.

18. Brody, A. R., and L. H. Hill. 1982. Interstitial accumulation of inhaled chrysotile asbestos fibers and consequent formation of microcalcifications. Am.J. Pathol. 109:107.

19. Chang, L., L. H. Overby, A. R. Brody, and J. D. Crapo. 1988. Progressive lung cell reactions and extracellular matrix production after a brief exposure to asbestos. Am. J. Pathol. 131:156-170. 
20. Craighead, J. E., and B. T. Mossman. 1982. The pathogenesis of asbestosassociated diseases. $N$. Engl. J. Med. 306:1446-1455.

21. Crystal, R. G., J. E. Gadek, V. J. Ferrans, B. R. Line, and G. W. Hunninghake. 1981. Interstitial lung diseases: current concepts of pathogenesis, staging and therapy. Am. J. Med. 70:542-568.

22. Chomczynski, P., and N. Sacchi. 1987. Single-step method RNA isolation by acid quanidinium thiocyanate-phenol-chloroform extraction. Anal. Biochem. 162:156-158.

23. Claesson-Welsh, L., A. Eriksson, B. Westermark, and C.-H. Heldin. 1989. cDNA cloning and expression of the human A-type platelet-derived growth factor (PDGF) receptor establishes structural similarity to the B-type PDGF receptor. Proc. Natl. Acad. Sci. USA. 86:4917-4921.

24. Scatchard, G. 1949. The attraction of proteins for small molecules and ions. Ann. NY Acad. Sci. 51:660.

25. Perderiset, M., J. P. Marsh, and B. T. Mossman. 1991. Activation of protein kinase $\mathrm{C}$ by crocidolite asbestos in hamster tracheal epithelial cells. Carcinogenesis (Eynsham). 12:1499-1502.

26. Sesko, A., M. Cabot, and B. T. Mossman. 1990. Hydrolysis of inositol phospholipids precedes cellular proliferation in asbestos-stimulated tracheobronchial epithelial cells. Proc. Natl. Acad. Sci. USA. 87:7385-7389.

27. Tsukamoto, T., T. Matsui, H. Nakata, M. Ito, T. Natazuka, M. Fukase, and T. Fujita. 1991. Interleukin-1 enhances the response of osteoblasts to plateletderived growth factor through the $\alpha$ receptor-specific up-regulation. J. Biol. Chem. 266:10143-10147.

28. Schollman, C., R. Grugel, D. Tatje, J. Hoppe, J. Folkman, D. Marme, and H. A. Weich. 1992. Basic fibroblast growth factor modulates the mitogenic potency of the platelet-derived growth factor (PDGF) isoforms by specific up-regulation of the PDGF $\alpha$-receptor in vascular smooth muscle cells. J. Biol. Chem. 267:18032-18039.

29. Battegay, E. J., E. W. Raines, R. A. Seifert, D. F. Bowen-Pope, and R. Ross. 1990. TGF- $\beta$ induces bimodal proliferation of connective tissue cells via complex control of an autocrine PDGF loop. Cell. 63:515-524.

30. Gronwald, R. G. K., R. A. Seifert, and D. F. Bowen-Pope. 1989. Differen- tial regulation of expression of two platelet-derived growth factor receptor subunits by transforming growth factor $\beta$. J. Biol. Chem. 264:8120-8125.

31. Yamakage, A., K. Kikuchi, E. A. Smith, E. C. LeRoy, and M. Trojanowska. 1992. Selective upregulation of platelet-derived growth factor $\alpha$-receptors by transforming growth factor- $\beta$ in scleroderma fibroblasts. J. Exp. Med. 175:1227-1234.

32. Warheit, D. B., L. H. Overby, G. George, and A. R. Brody. 1988. Pulmonary macrophages are attracted to inhaled particles through complement activation. Exp. Lung Res. 14:51-66.

33. Brody, A. R., and L. H. Overby. 1989. Incorporation of tritiated thymidine by epithelial and interstitial cells in bronchiolar-alveolar regions of asbestosexposed rats. Am. J. Pathol. 134:133-140.

34. McGavran, P. D., L. B. Moore, and A. R. Brody. 1990. Inhalation of chrysotile asbestos induces rapid cellular proliferation in small pulmonary vessels of mice and rats. Am. J. Pathol. 136:695-705.

35. Raines, E. W., S. K. Dower, and R. Ross. 1989. IL-1 mitogenic activity for fibroblasts and smooth muscle cells is due to PDGF-AA. Science (Wash. DC). 243:393-396.

36. Hosang, M., M. Rouge, B. Wipf, B. Eggimann, F. Kaufmann, and W. Hunziker. 1989. Both homodimeric isoforms of PDGF (AA and BB) have mitogenic and chemotactic activity and stimulate phosphoinositol turnover. J. Cell. Physiol. 140:295-304.

37. Siegbahn, A., A. Hammacher, B. Westermark, and C.-H. Heldin. 1990 Differential effects of the various isoforms of platelet-derived growth factor on chemotaxis of fibroblasts, monocytes, and granulocytes. J. Clin. Invest. 85:916920.

38. Lasky, J. A., A. R. Brody, and J. C. Bonner. 1992. Rat lung fibroblasts are stimulated to secrete platelet-derived growth factor and to proliferate in vitro by chrysotile asbestos fibers. Am. Rev. Respir. Dis. 145:A796. (Abstr.)

39. Nagaoka, I., B. C. Trapnell, and R. G. Crystal. 1990. Upregulation of platelet-derived growth factor-A and -Bgene expression in human alveolar macrophages of individuals with idiopathic pulmonary fibrosis. J. Clin. Invest. 85:2023-2027. 